\title{
Acute reduction of arterial blood pressure reduces urinary albumin excretion in Type 1 (insulin-dependent) diabetic patients with incipient nephropathy
}

\author{
E. Hommel, E. Mathiesen, B. Edsberg, M. Bahnsen and H.-H. Parving \\ Hvidöre Hospital, Klampenborg, Denmark
}

\begin{abstract}
Summary. The effect of an acute reduction in arterial blood pressure upon kidney function was studied in 12 patients with Type 1 (insulin-dependent) diabetes and incipient nephropathy (persistent microalbuminuria). Renal function was assessed by measurement of the glomerular filtration rate (single bolus ${ }^{51} \mathrm{Cr}$-EDTA technique) and by the urinary albumin excretion rate (radioimmunoassay). The study was performed twice within 2 weeks, with the patients receiving a slow intravenous injection of either clonidine $(225 \mu \mathrm{g})$ or saline $(154 \mathrm{mmol} / \mathrm{l})$ in random order. Clonidine reduced arterial blood pressure from $125 / 79 \pm 13 / 8$ to $104 / 68 \pm 9 / 7 \mathrm{mmHg}$ $(p<0.01)$, urinary albumin excretion rate from $68(31-369)$ to $46(6-200) \mu \mathrm{g} / \mathrm{min}$ (median and range) $(p<0.01)$, and frac-
\end{abstract}

tional clearance of albumin in all patients (median 29\%) $(p<$ 0.01 ). Glomerular filtration rate was $110 \pm 11$ before and $106 \pm 13 \mathrm{ml} / \mathrm{min} / 1.73 \mathrm{~m}^{2}$ after clonidine injection. The blood glucose concentration was $15 \pm 4 \mathrm{mmol} / 1$ before and $14 \pm$ $5 \mathrm{mmol} / 1$ after clonidine injection. In agreement with findings in animal studies, our results suggest that microalbuminuria is to a large extent pressure-dependent, probably because of glomerular hypertension, and that autoregulation of glomerular filtration rate is normal in most patients with incipient diabetic nephropathy.

Key words: Autoregulation, arterial blood pressure, glomerular filtration, incipient diabetic nephropathy, Type 1 diabetes.
Approximately 40 percent of all Type 1 (insulin-dependent) diabetic patients ultimately develop the clinical syndrome of diabetic nephropathy: persistent proteinuria associated with a decline in glomerular filtration rate (GFR) and elevated blood pressure [1-3]. Elevated blood pressure accelerates $[4,5]$, and effective blood pressure reduction decelerates, the progression of nephropathy and reduces albuminuria [6, 7]. Several longitudinal studies have recently demonstrated that raised urinary albumin excretion (UAE) below the level of clinical proteinuria (Albustix), so-called microalbuminuria, strongly predicts the development of diabetic nephropathy in Type 1 diabetic patients [8-11]. Other studies [12-14] have suggested that the renal abnormality may still be reversible at this stage of incipient diabetic nephropathy $[11,15]$. These reversible factors may well be haemodynamic in origin. We therefore investigated the effect of acute blood pressure reduction upon urinary albumin excretion and glomerular filtration rate in Type 1 diabetic patients with incipient nephropathy.

\section{Subjects and methods}

\author{
Subjects \\ Twenty-four-hour home urine collections were obtained from all \\ Type 1 diabetic patients $(n=1254)$ visiting the outpatient clinic at Hvi- \\ döre Hospital in 1984. One hundred and seventy-six patients had uri-
}

nary albumin excretion rates in the microalbuminuric range: 20 to $200 \mu \mathrm{g} / \mathrm{min}$. Fifteen randomly selected patients with microalbuminuria were asked to perform six additional home 24-h urine collections. Two males were excluded because their UAE was persistently above $200 \mu \mathrm{g} / \mathrm{min}$, and one female was excluded because her UAE was below $20 \mu \mathrm{g} / \mathrm{min}$. The remaining 12 patients satisfied the following criteria: incipient nephropathy (see below), age less than 50 years, onset of insulin-dependent diabetes before the age of 31 years, no medication other than insulin and absence of frank arterial hypertension (Table 1). All had been insulin-dependent from the time of diagnosis, and all received two daily injections of insulin. All patients gave their informed consent, and the experimental design was approved by the local Ethical Committee.

Persistent microalbuminuria was defined as UAE between 20 to $200 \mu \mathrm{g} / \mathrm{min}$ in 2 out of 3 consecutive $24-\mathrm{h}$ collections of urine at home. Incipient diabetic nephropathy was diagnosed clinically if the following criteria were fulfilled: persistent microalbuminuria, sterile urine without ketonuria $(<2+)$, duration of diabetes more than 5 years, lack of frank arterial hypertension (systolic BP $>160 \mathrm{mmHg}$, diastolic $\mathrm{BP}>105 \mathrm{mmHg}$ ), and no history of kidney or urinary tract disease.

\section{Methods}

The study was performed twice within 2 weeks, and the patients received a slow intravenous injection $(10 \mathrm{~min})$ at $08.40 \mathrm{~h}$ of either $225 \mu \mathrm{g}$, clonidine (Boehringer, Ingelheim, FRG) dissolved in $20 \mathrm{ml} \mathrm{sa-}$ line $(154 \mathrm{mmol} / \mathrm{l})$, or $20 \mathrm{ml}$ saline alone $(154 \mathrm{mmol} / \mathrm{l})$, in random order. The slow intravenous injection of clonidine was performed in an attempt to avoid the brief initial rise in blood pressure observed after a bolus injection of clonidine. The patients had no breakfast and no morning insulin before the investigations. Measurements were performed in the supine position and the patients stood only when void- 
Table 1. Clinical data for Type 1 (insulin-dependent) diabetic patients with incipient nephropathy

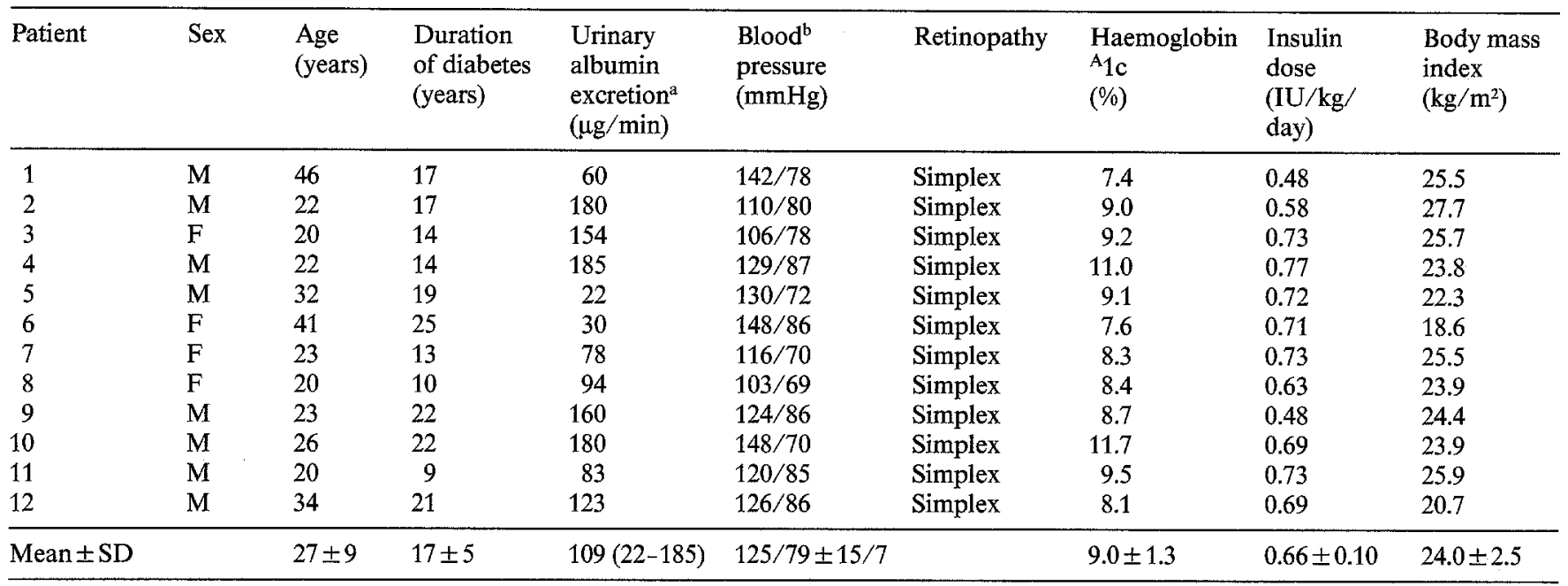

${ }^{a}$ Median of six 24-h urine collections at home; ${ }^{b}$ measured after $10 \mathrm{~min}$ rest in supine position

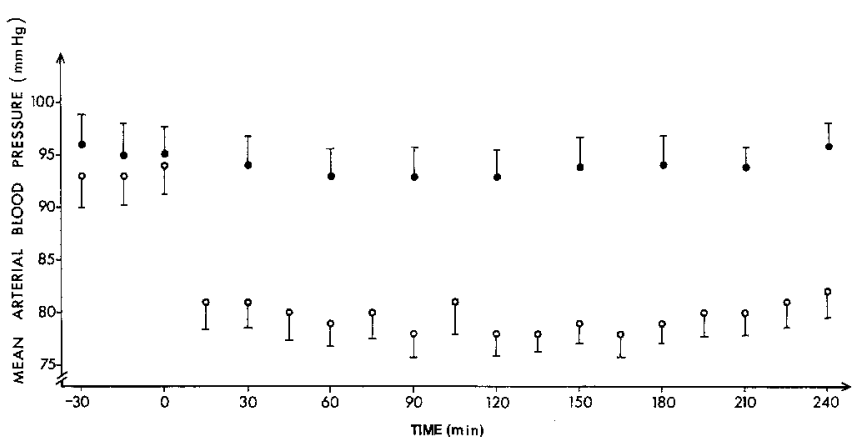

Fig. 1. Time course of mean arterial blood pressure response to an intravenous injection of $20 \mathrm{ml}$ saline $(154 \mathrm{mmol} / \mathrm{l})(\Theta)$, or clonidine $(225 \mu \mathrm{g})(\mathrm{o})$ in 12 Type 1 (insulin-dependent) diabetic patients with incipient nephropathy. The intravenous injections were given at time zero

ing. Urinary catheters were not used. The patients drank $200 \mathrm{ml}$ of tap water per $h$ during the study.

Glomerular filtration rate was measured after a single intravenous injection of ${ }^{51} \mathrm{Cr}$-EDTA $(09.00 \mathrm{~h})$ by studying the plasma disappearance for $4 \mathrm{~h}$ (normal value: $102 \pm 12 \mathrm{ml} / \mathrm{min} / 1.73 \mathrm{~m}^{2}$; mean $\pm S D$ ) [16]. The mean intraindividual coefficient of variation of GFR from day to day was $4.1 \%$. Urinary albumin excretion was measured during the 4 -h clearance period by radioimmunoassay [17]. This assay has a sensitivity of $0.5 \mathrm{mg} / 1$ and an interassay coefficient of variation of $9 \%$. Fractional clearance of albumin was obtained by dividing the clearance of albumin (calculated from $\mathrm{UV} / \mathrm{P}$; where $\mathrm{U}=$ urine albumin concentration; $\mathrm{V}=$ urine flow; $\mathrm{P}=$ plasma albumin concentration) by the simultaneously measured GFR. The coefficient of variation for UAE collected at home was $43 \%$.

Blood pressure was measured with a Hawksley random zero device, cuff $25 \times 12 \mathrm{~cm}$ (Hawksley \& Sons Ltd., West Sussex, UK), on the right arm. Blood pressure and heart rate were measured every $15 \mathrm{~min}$ during the clonidine and every $30 \mathrm{~min}$ during the saline runs. Diastolic blood pressure was recorded at the disappearance of the Korotkoff sounds (phase 5). Mean arterial blood pressure was calculated from diastolic blood pressure plus one third of the pulse amplitude. Blood glucose was measured every hour during the 4-h clearance period by the reflectance meter Reflomat (Boehringer-Mannheim, Mannheim, FRG). Plasma albumin was measured according to Laurell [18]. Stable haemoglobin $\mathrm{A}_{1 \mathrm{c}}\left(\mathrm{Hb}_{\mathrm{1c}}\right)$ was measured at the first investigation (normal range 4.1 to 6.1 percent of total haemoglobin)
[19]. Retinopathy was assessed by direct ophtalmoscopy after pupillary dilation. Vibratory perception threshold was measured in the big toe with a Biothesiometer (Bio-Medical Instruments Co., Newbury, $\mathrm{OH}$, USA). The threshold was expressed in volts, with a threshold $>$ $20 \mathrm{~V}$ being indicative of neuropathy in patients below the age of 45 .

\section{Statistical analysis}

Wilcoxon's nonparametric test for paired comparisons was used for statistical analysis. Values are given as mean \pm standard deviation (SD). Since urinary albumin excretion is not normally distributed, median and range are used.

\section{Results}

Intravenous clonidine injection induced a reduction in mean arterial blood pressure (MAP) of, on average, $14 \pm 5 \mathrm{mmHg}$. In 5 patients MAP was reduced just below $80 \mathrm{mmHg}$. The clonidine injection induced a stable reduction in mean arterial blood pressure (range $78-82 \mathrm{mmHg}$ ) during the 4-h clearance procedure (Fig. 1). Heart rate fell from $71 \pm 11$ to $65 \pm 9$ beats $/ \mathrm{min}$ $(0-240 \mathrm{~min})$ after the clonidine injection $(p<0.01)$.

UAE diminished in all 12 patients. After the clonidine injection median UAE was 46 (range 6-200) $\mu \mathrm{g} /$ min compared with a median pre-treatment level of 68 (range 31-375) $\mu \mathrm{g} / \mathrm{min}$ (Table $2, p<0.01$ ). There was no significant difference between the median UAE at home, 109 (range 22-185) $\mu \mathrm{g} / \mathrm{min}$, compared to UAE obtained during the 4-h control clearance procedure, median 68 (range 31-375) $\mu \mathrm{g} / \mathrm{min}$ (Tables 1 and 2). There was no significant difference in urine volume, mean $2.3 \pm 0.8 \mathrm{ml} / \mathrm{min}$ (before clonidine), and $1.9 \pm$ $0.7 \mathrm{ml} / \mathrm{min}$ after clonidine. GFR decreased in 7 patients, remained unchanged in 2 and rose in the remaining 3 patients, mean $110 \pm 11 \mathrm{ml} / \mathrm{min} / 1.73 \mathrm{~m}^{2}$ (before clonidine) and mean $106 \pm 13 \mathrm{ml} / \mathrm{min} / 1.73 \mathrm{~m}^{2}$ (after clonidine) $(p>0.10$, Table 1$)$. 
Table 2. Arterial blood pressure, urinary albumin excretion and glomerular filtration rate before and during acute blood pressure reduction in Type 1 (insulin-dependent) diabetic patients with incipient nephropathy

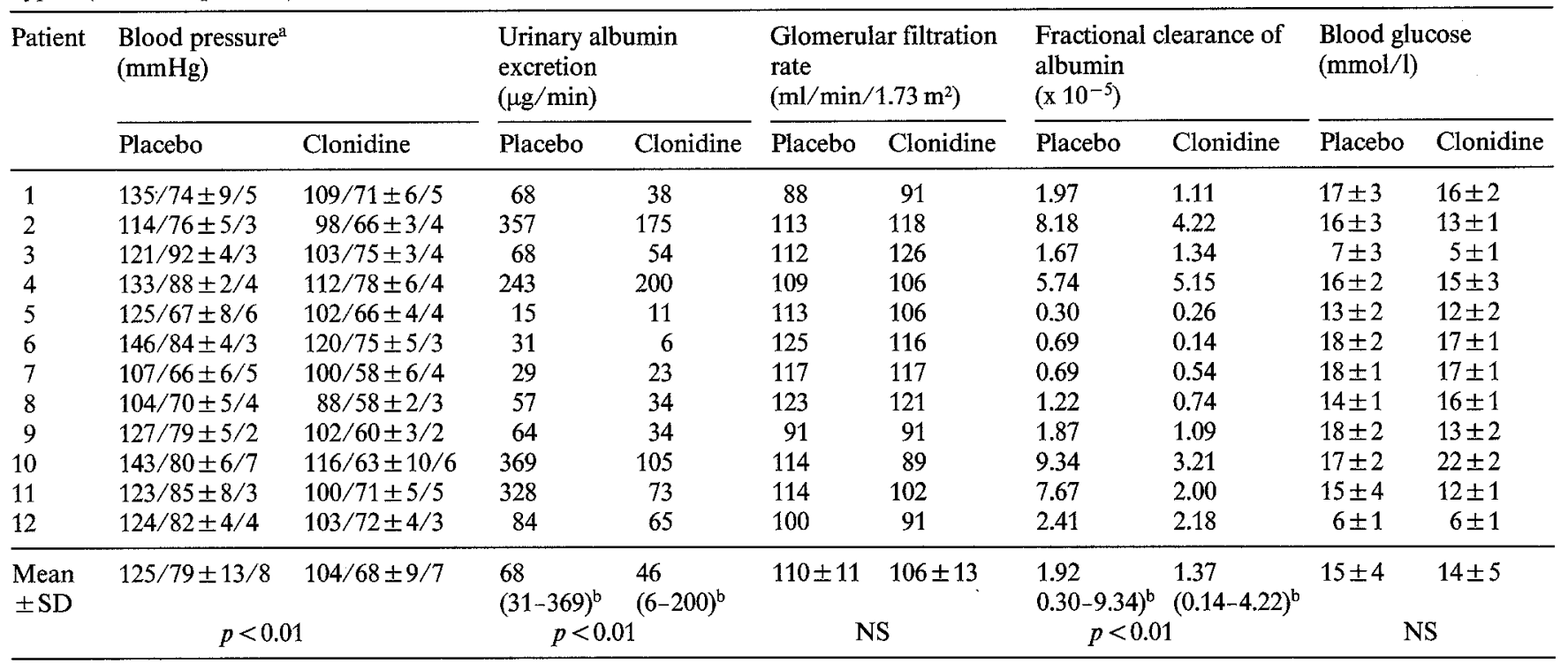

${ }^{\mathrm{a}}$ Mean of all measurements during the 4 -h clearance procedure; ${ }^{\mathrm{b}}$ median and range

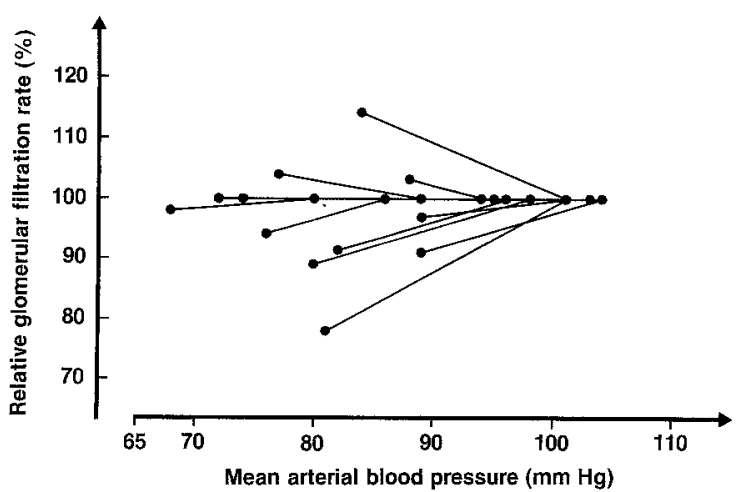

Fig. 2. Relative glomerular filtration rate (percentage of control GFR) and mean arterial blood pressure before and after intravenous injection of clonidine $(225 \mu \mathrm{g})$ in 12 Type 1 (insulin-dependent) diabetic patients with incipient nephropathy. The reduction in relative GFR fell below the lower limit of normal autoregulation ( $>10$ percent) in two patients [46]

Fractional clearance of albumin decreased in all 12 patients, median 29 percent (Table $2, p<0.01$ ).

The relationship between MAP and the relative GFR before and after acute blood pressure reduction is shown in Figure 2. The reduction in relative GFR was $>10$ percent in 2 of the 12 patients.

The blood glucose concentration, measured every $h$ during the 4-h clearance period, was nearly identical in the control studies (mean $15 \pm 4 \mathrm{mmol} / \mathrm{l}$ ) and the hypotensive studies (mean $14 \pm 5 \mathrm{mmol} / \mathrm{l}$ ).

All patients had vibratory perception thresholds below 20 volts. No side-effects, apart from dry mouth and sleepiness, were observed after the clonidine injection.

\section{Discussion}

We have demonstrated a considerable decrease in urinary albumin excretion ( 44 percent) and in fractional clearance of albumin ( 29 percent) during acute blood pressure reduction in insulin-dependent diabetic patients with incipient nephropathy. Several studies have demonstrated slightly elevated blood pressure in such patients $[11,20,21]$, and patients with a diabetes duration of more than 5 years have a greater increase in blood pressure in response to exercise than normal subjects [22]. Moderate exercise enhances urinary albumin excretion in Type 1 diabetic patients with and without micro- and macroalbuminuria, while UAE remains unchanged in healthy individuals $[23,24]$. Strict metabolic control reduces this abnormal response and diminishes UAE during everyday life in patients with microalbuminuria $[25,26]$. It seems highly unlikely that the present small difference in metabolic control in our study had any impact on UAE measured during the 4-h clearance procedure. The present and previous findings of a high day-to-day variation in UAE strongly suggest that repeated measurements should be performed in order to diagnose incipient and overt diabetic nephropathy $[10,27]$. In order to make a valid diagnosis of incipient diabetic nephropathy, we excluded patients suffering from poor metabolic control with ketonuria $(>2+)$ or from moderate to severe arterial hypertension, since both conditions per se enhance UAE [28, 29].

The present finding of a reduction in microalbuminuria during acute blood pressure reduction strongly suggests that reversible haemodynamic factors play an important role in the pathogenesis of microalbuminuria. The simplest explanation of our findings may, therefore, be the correct one: a reduction of glomerular capil- 
lary pressure is induced by the reduction in systemic arterial blood pressure.

It is well documented that hyperfiltration and hyperperfusion are frequently present in insulin-dependent diabetic patients without clinical microangiopathy $[30,31]$. Mogensen et al. [10] have suggested that patients with the highest rates of glomerular filtration early in the course of their diabetes have an increased risk of developing incipient and overt diabetic nephropathy. Glomerular filtration rate is within the normal range in the majority of patients suffering from incipient diabetic nephropathy [11, 20, 32], as also demonstrated in our study. However, single nephron GFR may well be elevated, due to the demonstrated reduction in functioning glomeruli in incipient diabetic nephropathy [33]. Elevated transglomerular hydrostatic pressure has been demonstrated in normotensive insulin-treated streptozotocin diabetic rats $[34,35]$. Arterial hypertension induces a marked elevation in glomerular capillary hydrostatic pressure in streptozotocin diabetic compared to non-diabetic spontaneous hypertensive rats, 52.6 versus $43.8 \mathrm{mmHg}$ [36]. Other studies have demonstrated that haemodynamic factors such as arterial hypertension, hyperfiltration, hyperperfusion and glomerular hypertension increase urinary albumin excretion and accelerate the development of glomerulopathy in streptozotocin diabetic rats [37-40]. Furthermore, UAE can be reduced and the haemodynamically-induced glomerular lesions mitigated by antihypertensive treatment or dietary protein restriction, which induces a reduction in hyperfiltration and glomerular capillary hydrostatic pressure [41, 42]. Effective antihypertensive treatment diminishes albuminuria and reduces the rate of decline in GFR in established diabetic nephropahty $[6,7]$.

These findings support the suggestion that elevated transglomerular hydrostatic pressure and increased transglomerular protein passage are important factors in the development and progression of diabetic glomerulopathy $[40,41,43]$. If, as suggested, enhanced leakage of plasma proteins through and their deposition in the walls of the microvasculature is involved in the development of diabetic microangiopathy, our results support the case for early effective treatment of blood pressure at much lower levels than those applied in the past.

The potential hazard of such a policy could be reduction of glomerular filtration rate below normal. Autoregulation of GFR, i. e. the maintenance of relative constancy of GFR despite variations in perfusion pressure induced by changing arterial blood pressure, is present in animals and man [44, 45]. Type 1 diabetic patients with nephropathy have impaired autoregulation of GFR, probably due to hyalinosis of the arterioles [46]. The present study shows that 10 of the 12 patients investigated had a normal autoregulation of GFR, i. e. $<10 \%$ reduction in relative GFR. The clinical significance of preserved autoregulation of GFR in incipient diabetic nephropathy is protection against a stepwise reduction in GFR ( $>10 \%$ of the pre-treatment values) at the initiation of antihypertensive treatment.

\section{References}

1. Knowles HC (1974) Magnitude of the renal failure problem in diabetes. Kidney Int $6: 2-7$

2. Deckert T, Poulsen JE, Larsen M (1978) Prognosis of diabetics with diabetes onset before the age of thirty-one. I. Survival, causes of death and complications. Diabetologia 14: 363-370

3. Andersen AR, Christiansen JS, Andersen JK, Kreiner S, Deckert T (1983) Diabetic nephropathy in Type 1 (insulin-dependent) diabetes: an epidemiological study. Diabetologia 25: 496-501

4. Berkman J, Rifkin H (1973) Unilateral nodular diabetic glomerulosclerosis (Kimmelstiel-Wilson). Report of a case. Metab Clin Exp 22: 715-722

5. Mauer SM, Steffes MW, Azar S, Sandberg SK, Brown DM (1978) The effect of Goldblatt hypertension on development of the glomerular lesions of diabetes mellitus in the rat. Diabetes 27: 738-744

6. Mogensen CE (1982) Long-term antihypertensive treatment inhibiting progression of diabetic nephropathy. Br Med J 285: 685-688

7. Parving H-H, Andersen AR, Smidt UM, Svendsen PAa (1983) Early aggressive antihypertensive treatment reduces rate of decline in kidney function in diabetic nephropathy. Lancet 1 : 1175-1179

8. Parving H-H, Oxenbøll B, Svendsen PAa, Christiansen JS, Andersen AR (1982) Early detection of patients at risk of developing diabetic nephropathy: a longitudinal study of urinary albumin excretion. Acta Endocrinol (Copenh) 100:550-555

9. Viberti GC, Hill RD, Jarrett RJ, Argyropaulos A, Mahmud Y, Keen H (1982) Microalbuminuria as a predictor of clinical nephropathy in insulin-dependent diabetes mellitus. Lancet 1: $1430-1432$

10. Mogensen CE, Christensen CK (1984) Predicting diabetic nephropathy in insulin-dependent patients. New Engl J Med 311: 89-93

11. Mathiesen ER, Oxenbøll B, Johansen K, Svendsen PAa, Deckert T (1984) Incipient nephropathy in Type 1 (insulin-dependent) diabetes. Diabetologia 26: 406-410

12. Viberti GC, Pickup JC, Jarrett RJ, Keen H (1979) Effect of control of blood glucose on urinary excretion of albumin and $\beta 2$ microglobulin in insulin-dependent diabetes. New Engl J Med 300: 638-641

13. The Kroc collaborative study group (1984) Blood glucose control and the evalution of diabetic retinopathy and albuminutia. New Engl J Med 311:365-372

14. Barnett $\mathrm{AH}$, Wakelin $\mathrm{K}$, Leatherdale BA, Britton JR, Polak A, Bennett J, Toop M, Rowe D, Dallinger K (1984) Specific thromboxane synthetase inhibition and albumin excretion rate in insulin-dependent diabetes. Lancet 1: 1322-1325

15. Mogensen CE, Christensen CK, Vittinghus E (1983) The stages in diabetic renal disease. With emphasis on the stage of incipient nephropathy. Diabetes 32 (Suppl 2): 64-78

16. Bröchner-Mortensen J, Giese J, Rossing N (1969) Renal insulin clearance versus total plasma clearance of ${ }^{51} \mathrm{Cr}$-EDTA. Scand $\mathbf{J}$ Clin Lab Invest 23: 301-305

17. Miles DW, Mogensen CE, Gundersen HJG (1970) Radioimmunoassay for urinary albumin using a single antibody. Scand J Clin Lab Invest 26:5-11

18. Laurell CB (1966) Quantitative estimation of proteins by electrophoresis in agarose gel containing antibodies. Analyt Biochem 15: $45-52$

19. Mortensen HB (1980) Quantitative determination of hemoglobin $A_{1 c}$ by thinlayer isoelectric focusing. J Chromatography 182 : 325-333 
20. Wiseman M, Viberti GC, Mackintosh D, Jarrett RJ, Keen H (1984) Glycaemia, arterial pressure and microalbuminuria in Type 1 (insulin-dependent) diabetes mellitus. Diabetologia 26: 401-405

21. Christensen CK (1984) Abnormal albuminuria and blood pressure rise in incipient diabetic nephropathy induced by exercise. Kidney Int 25: 819-823

22. Karlefors T (1966) Exercise test in male diabetes. Acta Med Scand, Suppl 499

23. Viberti GC, Jarrett RJ, McCartney M, Keen H (1978) Increased glomerular permeability to albumin induced by exercise in diabetic subjects. Diabetologia 14: 293-300

24. Mogensen CE, Vittingus E, Sølling K (1979) Abnormal albumin excretion after two provocative renal tests in diabetes: Physical ex" ercise and lysine injection. Kidney Int 16: 385-393

25. Viberti GC, Pickup JC, Bilous RW, Keen H, Mackintosh D (1981) Correction of exercise-induced microalbuminuria in insulin-dependent diabetes after 3 weeks of subcutaneous insulin infusion. Diabetes 30: 818-823

26. Koivisto VA, Huttunen NP, Kierikko P (1981) Continuous subcutaneous insulin infusion corrects exercise-induced albuminuria in juvenile diabetes. Br Med J 282: 778-779

27. Feldt-Rasmussen B, Mathiesen ER (1984) Variability of urinary albumin excretion in incipient diabetic nephropathy. Diabetic Nephropathy 3: 101-103

28. Parving H-H, Noer J, Deckert T, Ervin P-E, Nielsen SL, Lyngsøe J, Mogensen CE, Rørth M, Svendsen PAa, Trap-Jensen J, Lassen NA (1976) The effect of metabolic regulation on microvascular permeability to small and large molecules in short-term diabetics. Diabetologia 12: 161-166

29. Parving H-H, Jensen HQ, Mogensen CE, Ervin P-E (1974) Increased urinary albumin-excretion rate in benign essential hypertension. Lancet 1: 1190-1192

30. Mogensen CE (1972) Kidney function and glomerular permeability to macromolecules in juvenile diabetes. Dan Med Bull 19 (Suppl 3): 1-40

31. Christiansen JS, Gammelgaard J, Frandsen M, Parving H-H (1981) Increased kidney size, glomerular filtration rate and renal plasma flow in short-term insulin-dependent diabetics. Diabetologia $20: 451-456$

32. Feldt-Rasmussen B, Baker L, Deckert T (1985) Exercise as a provocative test in early renal disease in Type 1 (insulin-dependent) diabetes: albuminuric, systemic and renal haemodynamic responses. Diabetologia 28:389-396

33. Mauer SM, Steffes MW, Ellis EN, Sutherland DER, Brown DM, Goetz FC (1984) Structural-functional relationships in diabetic nephropathy. J Clin Invest 74: 1143-1155
34. Hostetter TH, Troy JL, Brenner BM (1981) Glomerular hemodynamics in experimental diabetes. Kidney Int 19:410-415

35. Jensen PK, Christiansen JS, Steven K, Parving H-H (1981) Renal function in streptozotocin-diabetic rats. Diabetologia 21: 409-414

36. Bank N, Klose R, Aynedjian HS (1985) Glomerular pressure in rats with diabetes and hypertension. Kidney Int 27: 241 (Abstract)

37. Steffes MW, Brown DM, Mauer SM (1978) Diabetic glomerulopathy following unilateral nephrectomy in the rat. Diabetes 27 : $35-41$

38. Hostetter TH, Olson JL, Rennke HG, Venkatachalam MA, Brenner BM (1981) Hyperfiltration in remnant nephrons: a potentially adverse response to renal ablation. Am J Physiol 241: F85-F93

39. Brenner BM (1983) Hemodynamically mediated glomerular injury and the progressive nature of kidney disease. Kidney Int 23: 647-655

40. Steffes MW, Brown DM, Mauer SM (1979) The development, enhancement, and reversal of the secondary complications of diabetes mellitus. Human Pathol 10: 293-299

41. Hostetter TH, Rennke HG, Brenner BM (1982) The case for intrarenal hypertension in the initation and progression of diabetic and other glomerulopathies. Am J Med 72: 375-380

42. Zatz R, Meyer TW, Dunn BR, Anderson S, DeGraphenried RL, Noddin JL, Nunn AW, Troy JL, Brenner BM (1985) Lowering of arterial pressure (MAP) limits glomerular hypertension and albuminuria in experimental diabetes. Kidney Int 27:252 (Abstract)

43. Parving $\mathrm{H}-\mathrm{H}$, Viberti GC, Keen $\mathrm{H}$, Cristiansen JS, Lassen NA (1983) Hemodynamic factors in the genesis of diabetic microangiopathy. Metabolism 32: 943-949

44. Selkurt EE, Hall PW, Spencer MP (1949) Influence of graded arterial pressure decrement on renal clearance of the creatinine, p-aminohippurate and sodium. Am J Phsyiol 159: 369-378

45. Thurau K (1964) Renal hemodynamics. Am J Med 36: 698-719

46. Parving H-H, Kastrup J, Smidt UM, Andersen AR, Feldt-Rasmussen B, Christiansen JS (1984) Impaired autoregulation of glomerular filtration rate in Type 1 (insulin-dependent) diabetic patients with nephropathy. Diabetologia 27: 547-552

Received: 4 December 1985

and in revised form: 17 February 1986

Dr. Eva Hommel

Hvidöre Hospital

Emiliekildevej 1

DK-2930 Klampenborg

Denmark 